\title{
PROGRAM BIMBINGAN DAN KONSELING UNTUK MENINGKATKAN KEPERCAYAAN DIRI SISWA
}

\author{
Patriana
}

\begin{abstract}
ABSTRAK
Penelitian ini secara umum bertujuan untuk merumuskan program bimbingan dan konseling untuk meningkatkan rasa percaya diri siswa, Secara khusus tujuan dari penelitian ini bertujuan untuk mendeskripsikan gambaran umum dan aspek rasa percaya diri dan menyusun rancangan program bimbingan dan konseling untuk meningkatkan rasa percaya diri pada siswa. Metode yang digunakan dalam penelitian ini adalah metode deskriptif. Deskriptif adalah metode penelitian dengan cara mengemukakan fakta-fakta yang ditemukan dari lapangan secara apa adanya pada saat penelitian berlangsung. Hasil penyebaran skala psikologis pada siswa kelas VIII SMP Negeri 17 Pontianak pada gambaran umum rasa percaya diri siswatergolong "tinggi". Disarankan kepada guru pembimbing didalam Penyusunan program hendaknya melakukan analisis kebutuhan terlebih dahulu supaya menghasilkan program yang sesuai dengan kebutuhan siswa dan Penyusunan program layanan bimbingan hendaknya dirumuskan secara khusus dan sesuai dengan kurikulum yang ada di sekolah.
\end{abstract}

Kata Kunci: Program Bimbingan dan Konseling, Rasa Percaya Diri

\section{A. Pendahuluan}

Pendidikan mempunyai peranan penting dalam membimbing, mendidik, melatih dan mengajar peserta didik menuju manusia seutuhnya. Tujuan inti dari pendidikan adalah perkembangan kepribadian secara optimal dari setiap peserta didik sebagai pribadi yang mandiri dan mampu menjalankan tugastugasnya agar mendapatkan hasil yang baik.Melalui pendidikan yang diselenggarakan di sekolah, peserta didik diajarkan untuk memiliki keyakinan terhadap dirinya sendiri, sehingga mereka dapat mencapai tujuan yang di inginkan. Hal ini sejalan dengan pendapat Hakim (2005: 6) yang menyatakan : "suatu keyakinan seseorang atau individu terhadap segala aspek kelebihan yang dimilikinya dan keyakinan tersebut membuat individu merasa mampu untuk mencapai 
berbagai tujuan didalam hidupnya". Keyakinan tersebut akan mencapai tujuan apabila mereka memiliki rasa percaya diri atau kepercayaan diri.

Percaya diri adalah modal dasar seorang manusia dalam memenuhi kebutuhan sendiri. Seseorang mempunyai kebutuhan untuk kebebasan berfikir dan berperasaan sehingga seseorang yang mempunyai kebebasan berfikir dan berperasaan akan tumbuh menjadi manusia dengan rasa percaya diri. Salah satu langkah pertama dan utama dalam membangun rasa percaya diri dengan memahami dan meyakini bahwa setiap manusia memiliki kelebihan dan kelemahan masingmasing. Kelebihan yang ada didalam diri seseorang harus dikembangkan dan dimanfaatkan agar menjadi produktif dan berguna bagi orang lain.

Rasa percaya diri sangat penting bagi siswa SMP yang sedang berada pada masa remaja.Hal ini sejalan dengan pendapat Asrori (2005:15) yang menyatakan bahwa "Fase remaja merupakan fase yang sangat potensial, baik dilihat dari segi kognitif, emosi maupun fisik". Siswa yang mempunyai rasa percaya diri yang tinggi akan menunjukkan perilaku, berupa adanya kemandirian dalam belajar, inisiatif, kreatif, dan selalu optimis serta kerja keras dalam segala hal. Selain itu
Santrock (2007: 26) menyatakan: "remaja diartikan sebagai masa perkembangan transisi antara masa anak-anak dan dewasa yang mencakup perubahan biologis, kognitif dan sosialemosional.

Masa remaja juga merupakan masa dimana mereka berusaha mencari jati diri yang sebenarnya.dalam pencarian tersebut, remaja banyak mendapat tantangan berupa timbulnya permasalahan-permasalahan yang harus di selesaikan. Permasalahan tersebut salah satunya di bidang pendidikan yang berkaitan yang berkaitan dengan proses belajar-mengajar yang berlangsung. Kurangnya rasa percaya diri yang di miliki dapat menjadi faktor penyebab munculnya permasalahan dalam belajar. Menurut Ardiwinata (2006: 33) menyebutkan beberapa perilaku yang menunjukan beberapa permasalahan dalam belajar yang sering di alami siswa yang kurang memiliki rasa percaya diri, diantaranya; takut menghadapi ulangan, tidak berani bertanya atau menyatakan pendapat, gugup saat tampil di kelas, dan sering mencontek saat tes.

Pada dasarnya, permasalahanpermasalahan belajar tersebut tidak akan muncul jika siswa memiliki rasa percaya diri yang tinggi. Rasa percaya diri ini sangat penting bagi siswa SMP yang sedang berada pada masa remaja. 
Hal ini sejalan dengan pendapat Asrori, 2005:15 yang menyatakan bahwa " fase remaja merupakan fase yang sangat potensial, baik dilihat dari segi koqnitif, emosi maupun fisik. Siswa yang mempunyai rasa percaya diri yang tinggi akan menunjukan perilakunya, berupa adanya kemandirian dalam belajar, inisiatif, kreatif, dan selalu optimis serta kerja keras dalam segala hal.

Kenyataannya, gejala-gejala kurangnya rasa percaya diri dalam belajar sering kita jumpai pada setiap jenjang pendidikan, terutama sekolah menengah, baik sekolah menengah pertama (SMP) maupun sekolah menengah atas (SMA). Pada sekolah menengah pertama, salah satunya SMP negeri 17 Pontianak, khususnya siswa kelas VIII dari hasil pra survei masih di temukan siswa yang menunjukan gejalagejala kurangnya rasa percaya diri dalam belajar. Seperti; sering mencontek, tidak berani bertanya atau menjawab pertanyaan yang di ajukan karena takut salah atau di tertawakan, selalu tergantung pada orang lain, gugup saat tampil di depan kelas dan selalu pesimis dalam menghadapi sesuatu

Bimbingan dan konseling merupakan salah satu kegiatan pendidikan yang memiliki posisi strategis dalam pengembangan kepribadian siswa.Untuk mengembangkan dan mengatasi masalah pribadi siswa di lakukan dengan pemberian layanan kepada para siswa, dan layanan tersebut disusun di dalam suatu program bimbingan dan konseling. Program diartikan sebagai suatu rancangan yang di lakukan dalam waktu tertentu. Hal ini sejalan dengan pendapat Winkel dan Hastuti (2006:91) menyatakan "Program Bimbingan (guidance program) yaitu suatu rangkaian kegiatan bimbingan yang terencana, terorganisasi dan terkoordinasi selama periode tertentu, misalnya satu tahun ajaran."

Suatu program bimbingan dapat disusun dengan berdasarkan suatu kerangka berpikir tertentu dan pola dasar pelaksanaan bimbingan tertentu.Kegiatan bimbingan mencakup tiga jenis bimbingan, yaitu bentuk bimbingan, sifat bimbingan dan ragam bimbingan yang masing-masing memmberikan corak tertentu pada kegiatan yang terampung dalam suatu program bimbingan.Di dalam program bimbingan terdapat beberapa komponen yang meliputi susunan saluran formal untuk melayani para siswa, tenagatenaga pendidik serta orang tua siswa.Agar program bimbingan dapat berjalan dengan lancar, efektif dan efisien, maka program tersebut harus di susun dengan melakukan perencanaan yang baik. 
Program bimbingan dan

konseling mempunyai kepedulian membantu para siswa dalam rangka mengembangkan potensi dirinya, dan mengatasi masalah atau kesulitan yang dialaminya.Seperti yang diungkapkan oleh Prayitno dan Erman Amti (2013: 29) bahwa permasalahan yang dialami para siswa di sekolah seringkali tidak dapat dihindari, meski dengan pengajaran yang baik sekalipun.Dalam kaitan itu, permasalahan siswa tidak dapat dibiarkan begitu saja.Di sinilah dirasakan perlunya bimbingan dan konseling.

Berdasarkan hasil wawancara kepada guru pembimbing, proses pemberian layanan masih dirasa kurang optimal karena proses layanan belum berdasarkan need assessment serta belum disusunnya program yang spesifik dalam mengatasi permasalahan kurangnya rasa percaya diri yang di alami oleh siswa.Berdasarkan permasalahan dan fenomena yang telah di paparkan di atas, maka peneliti ingin mengadakan penelitian tentang "Program Bimbingan dan Konseling Untuk Meningkatkan Rasa Percaya Diri Siswa". Rumusan masalah yang diajukan dalam penelitian ini adalah sebagai berikut: (1) Bagaimanakah gambaran umum dan aspek rasa percaya diri pada siswa?, (2) Bagaimanakah rancangan program bimbingan dan konseling untuk meningkatkan rasa percaya diri pada siswa?

Metode yang digunakan dalam penelitian ini adalah metode deskriptif. Deskriptif adalah metode penelitian dengan cara mengemukakan fakta-fakta yang ditemukan dari lapangan secara apa adanya pada saat penelitian berlangsung. Menurut Soeryabrata (2000:37) menyatakan : "Penelitian deskriptif adalah prosedur yang bertujuan membuat perencanaan serta sistematis, faktual,dan akurat mengenai fakta-fakta dan sifat-sifat populasi atau fenomena keadaan yang sedang terjadi".

Bentuk penelitian yang digunakan adalah survei ( survey ). Menurut Fraenkel dan Wallen (dalam Riyanto, 2001:23) bahwa "Penelitian survei adalah penelitian dengan mengumpulkan informasi dari suatu sampel dengan menanyakannya melalui angket atau interview supaya nantinya menggambarkan berbagai aspek dari populasi”. Berkenaan dengan hal ini, jalannya penelitian ini dilaksanakan dengan mengadakan survei langsung ke SMP Negeri 17 Pontianak untuk mengumpulkan dan menghimpun datadata beserta informasi berkenaan dengan program bimbingan dan konseling untuk meningkatkan rasa 
percaya diri siswa kelas VIII SMP Negeri 17 Pontianak.

Teknik pengumpulan data adalah cara yang digunakan untuk menghimpun data-data dan informasi yang diperlukan untuk menjawab masalah dan sub masalah sebagaimana telah dirumuskan sebelumnya Teknik pengumpulan data dalam penelitian ini menggunakan teknik komunikasi tidak langsung. Alat pengumpul data yang digunakan dalam penelitian ini sangat ditentukan oleh teknik pengumpul data yang digunakan pula.Penelitian ini menggunakan inventori karena menggambarkan langsung sifat dengan situasi yang ada pada diri siswa atau responden.Inventori merupakan teknik komunikasi tidak langsung yang berupa pernyataan.Sejalan dengan pendapat Kartini Kartono (2009: 260) yang menyatakan bahwa "inventori merupakan alat untuk menaksir dan menilai ada atau tidak adanya tingkah laku, minat sikap tertentu dan seterusnya, biasanya inventori ini berbentuk daftar pernyataan yang harus dijawab".

Inventori digunakan untuk memperoleh data tentang rasa percaya diri pada siswa kelas VIII Sekolah Menengah Pertama Negeri 17 Pontianak. Inventori yang digunakan adalah dalam bentuk terstruktur tertutup, artinya bahwa sejumlah pertanyaan telah tersedia sejumlah alternatif jawaban yang akan dipilih responden, sehingga responden hanya memberi tanda check list $(\sqrt{ })$ pada alternatif jawaban yang dianggapnya sesuai. Selain inventori, penelitian ini juga menggunakan alat pengumpul data lain yaitu pedoman wawancara dan observasi.Adapun analisis inventori siswa menggunakan perhitungan persentase dengan rumus sebagai berikut :

$$
\mathrm{X} \%=\frac{n}{N} \times 100 \%
$$

Keterangan

$$
\begin{aligned}
& \mathrm{X} \text { : Persentase yang dicari } \\
& \mathrm{n} \text { : Jumlah skor aktual jawaban } \\
& \mathrm{N} \text { : Jumlah skor maksimal ideal }
\end{aligned}
$$

\section{B. Pembahasan}

Hasil penelitian merupakan Analisis gambaran umum dan aspekaspek rasa percaya diri siswa kelas VIII SMP Negeri 17 Pontianakdimulai dengan memasukan data kualitatif menjadi data kuantitatif. Berikut hasil dari penyebaran inventori kepercayaan diri pada siswa kelas VIII SMP Negeri 17 Pontianak berdasarkan table tolok ukur kategori persentase.

TABEL 4.1

TOLOK UKUR KATEGORI PERSENTASE 
Berdasarkan tolok ukur pada Tabel

4.1 diperoleh hasil sebagaimana tertera pada tabel 4.2 .

TABEL 4.2

HASIL ANALISIS DATA GAMBARAN UMUM DAN ASPEK VARIABEL RASA PERCAYA DIRI

\begin{tabular}{|l|c|c|c|c|}
\hline $\begin{array}{c}\text { Aspek } \\
\text { Variabel }\end{array}$ & $\begin{array}{c}\text { Skor } \\
\text { Aktual }\end{array}$ & $\begin{array}{c}\text { Skor } \\
\text { Maksimal } \\
\text { Ideal }\end{array}$ & $\%$ & Ket \\
\hline $\begin{array}{l}\text { 1. Keyakinan } \\
\text { akan } \\
\text { kemampuan } \\
\text { diri }\end{array}$ & 970 & 1200 & 80,83 & Tinggi \\
\hline 2. Optimis & 818 & 960 & 85,20 & Tinggi \\
\hline \begin{tabular}{l} 
3. Objektif \\
\hline $\begin{array}{l}\text { 4. Bertanggung } \\
\text { jawab }\end{array}$
\end{tabular} & 414 & 480 & 86,25 & Tinggi \\
\hline $\begin{array}{l}\text { 5. Rasional } \\
\text { dan Realistis }\end{array}$ & 409 & 480 & 85,20 & Tinggi \\
\hline $\begin{array}{l}\text { Rasa Percaya } \\
\text { diri }\end{array}$ & 3025 & 3600 & 84,02 & Tinggi \\
\hline
\end{tabular}

\begin{tabular}{|c|c|c|}
\hline KATEGORI & $\begin{array}{c}\text { RENTANGAN } \\
\text { SKOR }\end{array}$ & $\begin{array}{c}\text { PERSENTASE } \\
(\%)\end{array}$ \\
\hline Tinggi & $81-120$ & $66,67-100$ \\
Sedang & $40-80$ & $33,34-66,66$ \\
Rendah & $0-39$ & $0-33,33$ \\
\hline
\end{tabular}

Berdasarkan tabel 4.2 di atas, dapat diketahui bahwa gambaran umum rasa percaya diri pada siswa kelas VIII SMP Negeri 17 Pontianakmencapai skor aktual 3025 dari skor maksimal ideal 3600. Berarti mencapai $84,02 \%$. Dengan demikian rasa percaya diri pada siswa kelas VIII SMP Negeri 17 pontianak tergolong "tinggi". Untuk dapat melihat gambaran umum rasa percaya diri siswasecara lebih rinci, maka perlu dilihat aspek-aspeknya. Jika dilihat dari aspek-aspeknya maka tampak bahwa :

a. Aspek keyakinan akan kemampuan dirimencapai skor maksimal aktual 970 dari skor maksimal ideal 1200, berarti mencapai $80,83 \%$. Dengan demikian keyakinan akan kemampuan diri sendiri pada siswa kelas VIII SMP Negeri 17 Pontianak dapat dikategorikan tinggi. Ini dapat ditafsirkan bahwa siswa selalu percaya pada kemampuannya dan menyelesaikan tugas dengan seluruh kemampuan yang dimiliki. Hanya saja masih ada diantara mereka selalu melakukan pekerjaan dengan bantuan orang lain.

b. Aspek optimismencapai skor aktual 818 dari skor maksimal ideal 960, berarti mencapai 85,20\%. Dengan demikian rasa optimis pada siswa kelas VIII SMP Negeri 17 Pontianak dapat dikategorikan tinggi. mater. Ini dapat ditafsirkan bahwa siswa selalu optimis terhadap apa yang akan mereka kerjakan. Mereka juga tekun serta bekerja keras dalam melakukan sesuatu, serta tidak mudah menyerah saat mengalami kesulitan. Hanya saja masih ada 
diantara mereka yang mudah menyerah dalam melakukan sesuatu.

c. Aspek objektif mencapai skor maksimal aktual 414 dari skor maksimal ideal 480, berarti mencapai $86,25 \%$. Dengan demikian sifat objektif siswa dapat dikategorikan tinggi. Ini dapat ditafsirkan bahwa siswa menyadari bahwa mereka mempunyai kelebihan dan mampu mempertimbangkan dengan baik setiap pilihan yang akan diambilnya. Hanya saja masih ada diantara mereka yang kurang mampu dalam mengembangkan kelebihan yang dimiliki.

d. Aspek bertanggung jawab mencapai skor maksimal aktual 414 dari skor maksimal 480. Berarti mencapai 86,25\%. Dengan demikian rasa bertanggung jawab siswa dapat dikategorikan tinggi. Ini dapat ditafsirkan bahwa siswa selalu mampu untuk menerima konseksuensi dalam melaksanakan tugas. Hanya saja masih ada diantara mereka yang tidak melaksanakan tugas secara optimal

e. Aspek rasional dan realistis mencapai skor aktual 409 dari skor maksimal 480. Berarti mencapai
$85,20 \%$. Dengan demikian cara berfikir rasional dan realistis siswa kelas VIII SMP Negeri 17 Pontianak dapat dikategorikan tinggi. Ini dapat ditafsirkan bahwa siswa berusaha untuk menganalisa suatu masalah dengan logis. Mereka juga memandang setiap permasalahan yang muncul merupakan tantangan yang harus dilalui. Hanya saja masih ada diantara mereka yang masih ragu dalam membuat keputusan.

Program bimbingan dan konseling dalam meningkatkan rasa percaya diri siswa dapat dirancang dengan sistematika sebagai berikut:

\section{a. Rasional}

Undang-undang RI Nomor 20 Tahun 2003 Tentang Sistem Pendidikan Nasional pasal 1 ayat 3 secara eksplisit menyatakan bahwa pendidikan pada hakikatnya merupakan usaha sadar dan terencana untuk mewujudkan suasana belajar dan proses pembelajaran agar peserta didik secara aktif mengembangkan potensi dirinya untuk memiliki kekuatan spiritual keagamaan, kepribadian, kecerdasan, akhlak mulia serta keperluan yang diperlukan dirinya, masyarakat bangsa dan negara. 
Artinya proses pendidikan yang dikembangkan harus menyentuh berbagai macam ragam dan aspek perkembangan peserta didik, baik secara individual peserta didik itu sendiri maupun tenaga pendidiknya. Proses ini tidak cukup hanya oleh guru mata pelajaran, melainkan juga profesi pendidik lainnya, yaitu konselor.

Badan Standar Nasional, 2007 menyatakan bahwa konselor profesional sebagai salah satu tenaga pendidik dipersyaratkan untuk memiliki kompetensi pedagogik, diantaranya: a) menguasai karakteristik peserta didik dari aspek fisik, moral, sosial, budaya, emosional dan intelektual; dan b) memfasilitasi pengembangan potensi peserta didik untuk mengaktualisasikan berbagai potensi yang dimilikinya. Pengembangan potensi peserta didik hanya dapat dilakukan dengan optimal apabila pendidik memberikan fasilitas dan proses pendidikan sesuai dengan karakteristik peserta didik, yang secara individual memerlukan upaya sistematis yang salah satunya penyusunan program bimbingan untuk mengembangkan rasa percaya diri.

\section{b. Visi dan Misi}

1) Visi

"Meningkatkan rasa percaya diri pada siswa SMP Negeri 17 Pontianak".

2) Misi

a) Memfasilitasi siswa untuk memiliki keyakinan akan kemampuan diri dengan baik.

b) Memfasilitasi siswa untuk memiliki rasa optimis dengan baik.

c) Memfasilitasi siswa untuk memiliki penilaian objektif dengan baik.

d) Memfasilitasi siswa untuk memiliki rasa bertanggung jawab dengan baik.

e) Memfasilitasi siswa untuk memiliki cara berfikir yang rasional dan realistis dengan baik.

\section{c. Tujuan Program}

Secara umum tujuan program ini adalah untuk meningkatkan rasa percaya diri pada siswa kelas VIII SMP Negeri 17 Pontianak. Secara khusus program bimbingan rasa percaya diri bertujuan agar:

1) Siswa memiliki keyakinan akan kemampuan diri, tidak tergantung dengan orang lain, mampu 
mengendalikan diri serta berani menjadi diri sendiri.

2) Siswa memiliki rasa optimis yang tinggi, keyakinan untuk berhasil, tekun dan tidak mudah putus asa, bisa memotivasi diri bersikap positif terhadap kegagalan.

3) Siswa memiliki penilaian diri secara objektif, dan objektif dalam mempertimbangkan pilihan.

4) Siswa memiliki rasa tanggung jawab, mampu melaksanakan tugas dengan baik serta bersedia menerima setiap konsekuensi.

5) Siswa mampu berfikir secara logis dan berfikir positif terhadap suatu permasalahan.

\section{d. Komponen Program dan Strategi Pengembangan}

Komponen dan strategi
dilaksanakan sesuai dengan
kebutuhan siswa tentang rasa percaya diri tentunya berdasarkan hasil analisis kebutuhan sehingga tidak terjadi kesalahan dalam pemberian bantuan. Karena tingkat rasa percaya diri siswa tergolong tinggi maka komponen dan strategi yang akan diberikan antara lain layanan informasi dan layanan bimbingan dan kelompok. Untuk lebih jelas, komponen dan strategi tersebut dijabarkan sebagai berikut:

1) Layanan Informasi

Layanan informasi yang diberikan dalam layanan ini adalah informasi-informasi yang berkenaan dengan rasa percaya diri sehingga nantinya siswa mampu untuk mengembangkan rasa percaya diri yang dimilikinya. Untuk lebih jelasnya, pelaksanaan layanan ini dapat dilihat pada tabel 4.3

TABEL 4.3

LAYANAN INFORMASI RASA PERCAYA DIRI

\begin{tabular}{|c|c|}
\hline a. Pengertian & $\begin{array}{l}\text { Layanan bimbingan yang } \\
\text { memungkinkan peserta } \\
\text { didik dapat menerima dan } \\
\text { memahami berbagai } \\
\text { informasi diri yang dapat } \\
\text { dipergunakan sebagai } \\
\text { bahan pertimbangan dan } \\
\text { pengambilan keputusan } \\
\text { sehari-hari sebagai pelajar, } \\
\text { anggota keluarga dan } \\
\text { masyarakat }\end{array}$ \\
\hline b. Tujuan & $\begin{array}{l}\text { Membekali siswa dengan } \\
\text { berbagai pengetahuan dan } \\
\text { pemahaman tentang } \\
\text { berbagai hal yang berguna } \\
\text { untuk mengenal diri, } \\
\text { khususnya dalam } \\
\text { meningkatkan rasa percaya } \\
\text { diri sebagai seorang pelajar, } \\
\text { anggota keluarga maupun } \\
\text { masyarakat. }\end{array}$ \\
\hline c. Materi & 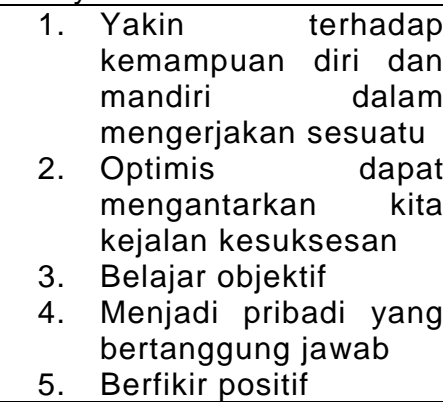 \\
\hline d. Metode & $\begin{array}{l}\text { 1. Ceramah } \\
\text { 2. Diskusi }\end{array}$ \\
\hline
\end{tabular}




\begin{tabular}{|l|l|}
\hline & $\begin{array}{l}\text { 3. Tanya Jawab } \\
\text { 4. Alat-alat peraga } \\
\text { 5. Tugas }\end{array}$ \\
\hline
\end{tabular}

2) Layanan Bimbingan Kelompok

Layanan ini merupakan kegiatan kelompok siswa yang bertujuan membantu mereka menyusun rencana dan keputusan yang tepat, kemampuan hubungan sosial, kegiatan belajar, serta melakukan kegiatan tersebut melalui dinamika kelompok.Kegiatan dalam bimbingan kelompok adalah pemberian informasi untuk keperluan tertentu bagi para anggota kelompok.Pembahasan dalam bimbingan kelompok dilakukan secara bersama-sama mengenai aspek-aspek rasa percaya diri. Untuk lebih jelasnya, pelaksanaan layanan ini dapat dilihat pada tabel 4.4

TABEL 4.4

LAYANAN BIMBINGAN KELOMPOK RASA PERCAYA DIRI

\begin{tabular}{|c|c|}
\hline a. Pengertian & $\begin{array}{lr}\text { Layanan } & \text { bimbingan } \\
\text { kelompok yaitu } & \begin{array}{r}\text { layanan } \\
\text { yimbingan }\end{array} \\
\text { memungkinkan sejumlah } \\
\text { peserta didik } & \text { secara } \\
\text { bersama-sama memperoleh } \\
\text { berbagai bahan/informasi } \\
\text { dari narasumber (terutama } \\
\text { dari pembimbing/konselor) } \\
\text { yang berguna untuk } \\
\text { menunjang kehidupannya } \\
\text { sehari-hari baik sebagai } \\
\text { individu, sebagai pelajar, } \\
\text { anggota keluarga dan } \\
\text { masyarakat serta untuk } \\
\text { mempertimbangkan dalam }\end{array}$ \\
\hline
\end{tabular}

\begin{tabular}{|c|c|}
\hline & $\begin{array}{lr}\text { mengambil } & \text { setiap } \\
\text { keputusan } & \text { dengan } \\
\text { memanfaatkan } & \text { dinamika } \\
\text { kelompok. } & \end{array}$ \\
\hline b. Tujuan & \begin{tabular}{lr} 
Untuk & \multicolumn{2}{r}{ memperoleh } \\
informasi, yang mana \\
informasi tersebut akan \\
dipergunakan & untuk \\
menyusun rencana dan \\
membuat keputusan atau \\
keperluan lain yang relevan \\
dengan informasi yang \\
diberikan terutama masalah \\
rasa percaya diri siswa.
\end{tabular} \\
\hline c. Materi & $\begin{array}{l}\text { 1. Keyakinan akan } \\
\text { kemampuan diri } \\
\text { 2. Optimis } \\
\text { 3. Objektif } \\
\text { 4. Bertanggung jawab } \\
\text { 5. Berfikir positif }\end{array}$ \\
\hline d. Teknik & $\begin{array}{l}\text { 1. Diskusi } \\
\text { 2. Dinamika kelompok } \\
\text { 3. Metode Tugas } \\
\text { 4. Sosiodrama }\end{array}$ \\
\hline
\end{tabular}

\section{e. Prosedur Program}

Prosedur bimbingan dan konseling dilaksanakan melalui pemberian layanan informasi secara klasikal dan bimbingan kelompok. Program ini dapat terlaksana dengan dukungan:

\section{Sasaran Kegiatan}

Sasaran kegiatan ini adalah siswa kelas VIII SMP Negeri 17 Pontianak, karena tingkat rasa percaya diri siswa termasuk pada kategori tinggi, fungsi yang diberikan bersifat pemeliharaan dan pengembangan serta diberikan layanan informasi dan layanan bimbingan kelompok. 


\section{Ruang Lingkup Program}

$$
\text { Program ini dikhususkan }
$$

dalam bidang pribadi-sosial, dan akademik yang bertujuan untuk meningkatkan rasa percaya diri siswa kelas VIII SMP Negeri 17 Pontianak melalui layanan bimbingan.

\section{Pelaksanaan}

\section{Pelaksanaan}

program

bimbingan ini adalah seluruh staf BK sekolah, bekerja sama dengan guru bidang studi atau wali kelas untuk sama-sama mengajarkan, membimbing, dan melatih siswa untuk meningkatkan rasa percaya diri secara optimal, baik di kelas maupun diluar kelas.

Secara rinci tugas dan tanggung jawab masing-masing personil, serta organisasi bimbingan percaya diri disekolah dapat dirinci sebagai berikut:

a. Kepala Sekolah
1) Mengkoordinasikan seluruh kegiatan layanan bimbingan percaya diri di sekolah
2) Menyediakan dan melengkapi sarana dan prasarana yang diperlukan dalam kegiatan bimbingan percaya diri di sekolah

3) Mengontrol pelaksanaan bimbingan percaya diri di sekolah

4) Menetapkan koordinator guru pembimbing yang bertanggung jawab atas koordinasi pelaksanaan bimbingan percaya diri di sekolah berdasarkan kesepakatan bersama guru pembimbing.

b. Wakil Kepala Sekolah

1) Mengkoordinasikan pelaksanaan layanan bimbingan percaya diri kepada semua personel sekolah

2) Melaksanakan kebijakan pimpinan sekolah terutama dalam pelaksanaan layanan bimbingan percaya diri.

c. Koordinator Bimbingan dan Konseling

1) Mengkoordinasikan para guru pembimbing dalam hal:
a) Memasyarakatkan pelayanan bimbingan percaya diri
b) Menyusun program bimbingan percaya diri
c) Melaksanakan program bimbingan percaya diri
d) Mengadministrasikan kegiatan bimbingan percaya diri 

e) Menilai program bimbingan percaya diri
f) Mengadakan tindak lanjut

2) Membuat usulan kepada kepala sekolah dan mengusahakan terpenuhinya tenaga, sarana dan prasarana

3) Mempertanggung jawabkan Pelaksanaan kegiatan bimbingan percaya diri di sekolah.

d. Guru Pembimbing

1) Memasyarakatkan kegiatan bimbingan percaya diri, terutama kepada siswa

2) Merencanakan program bimbingan percaya diri bersama koordinator BK

3) Merumuskan persiapan kegiatan bimbingan percaya diri

4) Melaksanakan layanan bimbingan percaya diri terhadap siswa yang menjadi tanggung jawabnya

5) Mengevaluasi proses dan hasil kegiatan layanan bimbingan percaya diri dan menganalisis hasil evaluasi

6) Melaksanakan tindak lanjut berdasarkan hasil analisis

7) Mengadministrasikan kegiatan bimbingan percaya diri
8) Mempertanggung jawabkan tugas dan kegiatan kepada koordinator guru pembimbing atau kepada kepala sekolah

9) Berpartisipasi aktif dalam berbagai kegiatan sekolah yang menunjang peningkatan mutu pendidikan di sekolah.

e. Guru mata pelajaran

1) Membantu memasyarakatkan layanan bimbingan percaya diri kepada siswa

2) Melakukan kerja sama dengan guru pembimbing dalam mengidentifikasi siswa yang memerlukan bimbingan percaya diri

3) Merujuk siswa yang memerlukan bimbingan percaya diri kepada guru pembimbing

4) Membantu mengumpulkan informasi yang diperlukan dalam rangka penilaian layanan bimbingan percaya diri

f. Wali Kelas

1) Membantu guru pembimbing melaksanakan layanan bimbingan percaya diri yang menjadi tanggung jawabnya

2) Membantu memberikan kesempatan kepada siswa, khususnya dikelas yang menjadi 
tanggung jawabnya untuk mengikuti layanan bimbingan percaya diri

3) Memberikan informasi tentang keadaan siswa kepada guru pembimbing untuk memperoleh layanan percaya diri

4) Ikut mendukung kegiatan bimbingan percaya diri

\section{Metode}

Metode yang digunakan dalam program ini disesuaikan dengan jenis layanan yang digunakan. Pemberian layanan informasi dapat menggunakan metode ceramah, tanya jawab, alat-alat peraga dan tugas, sedangkan layanan bimbingan kelompok dapat menggunakan metode diskusi, dinamika kelompok dan sosiodrama.

\section{Fasilitas}

Fasilitas yang menunjang kegiatan pelaksanaan program ini diantaranya adalah ruang kelas beserta perlengkapan untuk bimbingan klasikal, bimbingan kelompok dan ruang khusus untuk konseling individual sebagai tindak lanjut kegiatan.

Sarana lain yang menunjang proses bimbingan adalah papan tulis,
OHP, chat, komputer dan in-focus, alat tulis dan sejumlah prasarana untuk simulasi. (apabila dipandang perlu dan sesuai dengan kebutuhan)

\section{Waktu dan Tempat}

Kegiatan layanan informasi dapat dilaksanakan dengan klasikal di kelas sesuai dengan jam tatap muka, sedangkan bimbingan kelompok dilaksanakan diruang bimbingan dan konseling atau tempat yang disepakati.

\section{Penutup}

Berdasarkan

hasilyang diperoleh melalui analisis kebutuhan siswa dalam penelitian ini, dapat dikemukakan kesimpulan sebagai berikut:

1. Gambaran umum rasa percaya diri yang dimiliki siswa kelas VIII SMP Negeri 17 Pontianak tergolong tinggi. Dengan gambaran aspek sebagai berikut:
a. Aspek keyakinan akan kemampuan diri tergolong tinggi

b. Aspek optimis tergolong tinggi

c. Aspek objektif tergolong tinggi

d. Aspek bertanggung jawab tergolong tinggi 

e. Aspek rasional dan realistis tergolong tinggi

2. Program bimbingan dan konseling dalam meningkatkan rasa percaya diri pada siswa kelas VIII SMP Negeri 17 Pontianak sudah tersusun berdasarkan analisis kebutuhan yang diperoleh dari aplikasi instrumentasi. Program yang dirancang mengacu pada pola 17+ dalam bimbingan dan konseling dengan mengambil dua jenis layanan, yaitu layanan informasi dan layanan bimbingan kelompok.

$$
\text { Berdasarkan kesimpulan di }
$$
atas, penulis mengemukakan beberapa saran sebagai berikut:

a. Penyusunan program hendaknya dilakukan analisis kebutuhan terlebih dahulu supaya menghasilkan program yang sesuai dengan kebutuhan siswa

b. Penyusunan program layanan bimbingan hendaknya dirumuskan secara khusus dan sesuai dengan kurikulum yang ada d sekolah

c. Hasil rancangan program rasa percaya diri ini dapat diuji cobakan kepada siswa kelas VIII SMP Neger 17 Pontianak

\section{Daftar Pustaka}

Ardiwinata, R. 2006. Perkembangan Sikap Percaya Diri Kecemasan Terhadap Motivasi di Lingkungan Sekolah. Jakarta: Raja Wali Press Arikunto, Suharsimi dan Cepi Safrudin Abdul Jabar.2004. Evaluasi Program PendidikanPedoman Teoritis Praktis Bagi Praktisi Pendidikan.Jakarta:Bumi Aksara Asrori, M. 2005.Perkembangan Peserta Didik. Malang: Wineka Media. 2013.

Psikologi

Pembelajaran. Bandung: CV Wacana Prima

Hakim, T. 2005.Mengatasi Rasa tidak Percaya Diri. Jakarta: Puspa Swara

Kartini Katono. (2009). Kamus Lengkap Psikologi. Jakarta: Rajawali Pers

M. Ali .1989.Penelitian Kependidikan, Prosedur dan Strategi. Bandung: Angkasa

Nurihsan, Achmad Juntika. 2006.

Bimbingan dan Konseling dalam Berbagai LatarKehidupan.

Bandung:Refika Aditama 2010. Strategi Layanan Bimbingan dan Konseling.Bandung:Refika Aditama Prayitno dan Erman Amti. 2013. DasarDasar Bimbingan dan Konseling. Jakarta: Rineka Cipta 
Santrock, Jhon.W. 2007. Remaja Edisi 11 jilid 1. Jakarta: Erlangga

Winkel, W.S dan Hastuti,M. M. Sri. 2006. Bimbingan dan Konseling di InstutiPendidikan, Jakarta: Media Abadi

Yusuf, Syamsu dan Nurihsan, Achmad Juntika. $2009 . \quad$ Landasan Bimbingan dan Konseling, Bandung: Remaja Rosdakarya 